\title{
The Role of Vitamin D in Respiratory Viral Infections and Other Infectious Diseases
}

\author{
S. B. Dyussenova ${ }^{1 *}$, M. Y. Gordiyenko ${ }^{1}$, M. S. Askarov², G. K. Tuleuova ${ }^{3}$, S. B. Suleimenova ${ }^{4}$, G. S. Khussainova ${ }^{4}$, B. I. Abisheva \\ ${ }^{1}$ Department of Pediatrics and Neonatology, NC JSC Medical University of Karaganda, Karaganda, Kazakhstan; ${ }^{2} \mathrm{NC}$ JSC Medical \\ University of Karaganda, Department of Surgical Diseases, Karaganda. St. Gogol 40, 100000, Kazakhstan; ${ }^{3} \mathrm{NC}$ JSC Medical \\ University of Karaganda, Department of Emergency Medicine, Anesthesiology and Reanimatology, Karaganda. St. Gogol 40, 100000, \\ Kazakhstan; ${ }^{4}$ NJSC "Astana Medical University", Department of Internal Diseases with Course in Geriatrics, Nur-Sultan, Kazakhstan
}

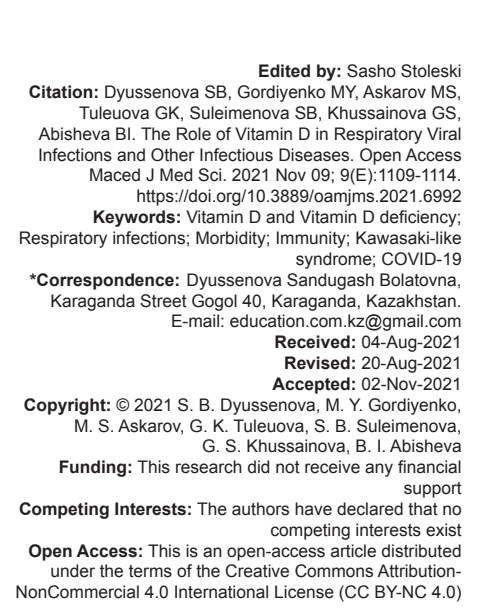

\section{Abstract}

BACKGROUND: Clinical studies and meta-analyzes have shown that reduced levels of 25-hydroxyvitamin D in the blood contribute to impaired immunity and stimulate excessive inflammation that adversely affects the health of children: The risk of developing bronchial asthma, obstructive bronchitis, and allergic rhinitis increases.

AIM: The main purpose of this review is to summarize the present literature data on the relationship between Vitamin D, VRI, and other infectious diseases with a clinical example.

MATERIALS AND METHODS: A comprehensive analysis was carried out under Vitamin D in respiratory viral infection and other diseases.

RESULTS: The results of fundamental research allow us to assert that Vitamin $D$ is fundamentally necessary for maintaining the normal physiological functioning of the immune system.

CONCLUSION: Clinical studies and meta-analyzes have shown that reduced levels of $25(\mathrm{OH}) \mathrm{E}$ in the blood contribute to impaired immunity and stimulate excessive inflammation, which adversely affects the health of children: The risk of developing bronchial asthma, obstructive bronchitis, and allergic rhinitis increases.

\section{Introduction}

At present, there are more than 7,200 publications in the databases of scientific publications on biomedicine (such as PUBMED and ELIBRARY), which present the results of fundamental and clinical studies on the role of Vitamin $D$ in supporting anti-infectious immunity [1], [2], [3], [4]. The results of fundamental research allow us to assert that Vitamin $D$ is fundamentally necessary to maintain the norm of the physiological functioning of the immune system: Activation of antibacterial and antiviral defense, reduction of excessive inflammation, etc. [5]. Vitamin D belongs to the group of fat-soluble vitamins, but due to its characteristics, the active form of the vitamin, or calcitriol, is called the $\mathrm{D}$-hormone. Vitamin $\mathrm{D}$ is naturally present in a very limited amount of food and synthesis in the human body is only possible under certain conditions, when the UV rays of sunlight hit the skin. Vitamin $D$, obtained from food and in the form of dietary supplements, as well as formed by exposure to the sun, is biologically inert; two hydroxylation processes must occur in the body to activate and convert to D-hormone. Vitamin D plays an important role in many metabolic processes in the human body. In recent years, interest in the extraosseous effects of Vitamin $D$ has increased, since a number of studies have revealed an association of its low values with an increased risk of some extraskeletal pathologies, including certain types of cancer, infections, autoimmune diseases, cardiovascular diseases, mental disorders, and kidney disease. Receptors to active metabolites of Vitamin D are present in most cells and tissues of the body, which also indicates the participation of Vitamin $D$ in the regulation of various biological functions [6].

Vitamin D, obtained from food and in the form of dietary supplements, as well as formed by exposure to the sun, is biologically inert. To activate and convert the hormone $(1,25$-hydroxyvitamin $\mathrm{D}$ [25 (OH) 2D]) into the active form $\mathrm{D}$, the body must undergo two hydroxylation processes. The first stage of hydroxylation occurs in the liver and converts Vitamin D to $25(\mathrm{OH}) \mathrm{D}$, also known as calcidiol. The second stage of hydroxylation occurs mainly in the kidneys (with the participation of the enzyme 
CYP27B1 - 1 $\alpha$-hydroxylase), and its result is the synthesis of the physiologically active D-hormone, 1, $25(\mathrm{OH}) 2 \mathrm{D}$ [7]. Blood levels of calcitriol are mainly determined by the activity of CYP27B1 in the kidney, under the control of parathyroid hormone, and tightly regulated by negative feedback, which is closed by inhibition of CYP27B1 by high concentrations of calcitriol itself and fibroblast growth factor 23 (FGF23). The limitation of the formation of the active form of the vitamin is facilitated by the stimulation of the enzyme CYP24A1 (24-hydroxylase), which converts calcitriol into an inactive, water-soluble form of calcitroic acid, which is subsequently excreted from the body with bile. FGF23, secreted primarily by osteocytes, that is, bone tissue, promotes the activation of 24-hydroxylase in response to high concentrations of Vitamin D hormone and an increase in the concentration of phosphorus in the blood [8], [9], [10].

Serum $25(\mathrm{OH})$ D concentration is the best indicator of Vitamin D status, as it reflects the total amount of Vitamin D produced in the skin and obtained from food and nutritional supplements (Vitamin D as a single drug or multivitamin and vitamin-mineral complexes), and has a fairly long half-life in blood - about 15 days [11]. Vitamin $\mathrm{D}$ deficiency, as defined by $25(\mathrm{OH}) \mathrm{D}$ levels of $<30 \mathrm{ng} /$ $\mathrm{ml}$ and $<20 \mathrm{ng} / \mathrm{ml}$, is widespread throughout the world.

At present, the deficiency, and to a greater extent the deficiency of $25(\mathrm{OH}) \mathrm{D}$, is a pandemic, affecting the majority of the general population, including children and adolescents [12]. The Vitamin D receptor is the main mediator of the biological action of Vitamin D. Vitamin D receptors are present in almost all tissues of the human body, which suggests that the functions of all cells are impossible without Vitamin D.

\section{Materials and Methods}

There have been many studies that studied not the effect of Vitamin D on phosphorus-calcium metabolism, but extraosseous processes with the participation of Vitamin D. Today, many processes are associated with the metabolism of Vitamin D. Vitamin D has crossed the boundaries of $\mathrm{Ca}$ and phosphate metabolism and has become a factor in providing the most important physiological functions. It can be considered as a steroid hormone with endocrine, paracrine, and autocrine effects.

Vitamin $D$ acts through its membrane receptor, which is found in cells of a wide variety of human organs and tissues, in particular, in most cells of the immune system and epithelial cells lining the mucous membranes. By binding to this receptor, Vitamin $\mathrm{D}$ goes into the cytoplasm, where it forms a complex with Vitamin A and its receptor. This complex either inhibits or enhances the transcription of hundreds of genes in nuclear DNA, including those that control cell growth, differentiation, apoptosis, and prevent malignant growth and angiogenesis.
The following effects of Vitamin $D$ on the immune system have been established: It weakens the presentation of antigen by dendritic cells, inhibits Th1 cell differentiation and production of Th1 cytokines, shifts the balance of Th1/Th2 cell responses toward the Th2 response, has an inhibitory effect on Th17 cells, and promotes development of Treg-cells and an increase in their activity. In addition, Vitamin D enhances the production of "endogenous antibiotics" that can have potent effects on Gram-positive and Gram-negative bacteria, fungi, and viruses. It turns out that Vitamin D is very important for the prevention of autoimmune and atopic diseases: Multiple sclerosis, rheumatoid arthritis, insulin-dependent diabetes, Crohn's disease, and ulcerative colitis; prevents the development of asthma in children, turns out to be an effective means of preventing and symptomatic treatment of chronic obstructive pulmonary diseases, protects against a wide range of infections, including tuberculosis, leprosy, and respiratory infections; and prevents the development of tumors in a number of organs.

Hypovitaminosis D, often hidden and undiagnosed, is present in almost half of the population of various countries and is one of the leading causes of weakened immunity and increased morbidity. Its identification, prevention, and treatment should be among the most important tasks of public health [13]. The incidence of acute respiratory infections (ARI) in the world is one of the highest [14], [15], [16], [17], [18], [19], [20], [21], [22], [23]. Observational studies indicate a strong correlation between low levels of 25-hydroxycalciferol, the main active metabolite of Vitamin D, and susceptibility to ARI [2], [3], [24], [25], [26], [27], [28], [29], [30], [31], [32], [33], [34], [35], [36], [37]. Vitamin $D$ has many biological effects due to its effect on the Vitamin $D$ receptor, which is present in most body tissues. The possible role of Vitamin $D$ in infections is explained by its influence on the mechanisms of innate and acquired immune responses. An important effect of Vitamin D is also its suppression of inflammatory processes.

Since Vitamin D deficiency belongs to the so-called "seasonal stimulants" of the development of ARVI by many scientists, the possibilities of preventive and therapeutic use of Vitamin $D$ during the ARVI and influenza season are of particular interest.

Severe acute respiratory syndrome coronavirus 2 (SARS-CoV-2) causes the ongoing pandemic coronavirus disease 2019 (COVID-19), affects cells in the lower respiratory tract, leading to a cytokine storm in a significant number of patients, resulting in severe pneumonia, shortness of breath, respiratory, and organ failure. Extensive research has shown the role of Vitamin $D$ in suppressing the cytokine storm in COVID-19 and reducing viral infection; however, the exact molecular mechanism is not yet known. In 2020, a study was published that used transcriptome 
data and identified 108 differentially expressed host genes (DEHG) in normal human bronchial epithelium cells infected with SARS-CoV-2, compared to controls. DEHGs were then integrated with human protein-protein interactions to create a SARS-CoV-2 (SiHgrn)-induced regulatory host gene network.

An in-depth analysis and study of the literature showed that Vitamin D binds to its receptor and can act in two different ways: (i) It suppresses the expression of pro-inflammatory cytokines by blocking the TNFinduced signaling pathway NFkB1; and (ii) it initiates the expression of genes that stimulate interferon (IFN). This comprehensive study has identified pathways associated with the cytokine storm in SARS-CoV-2 infection. The proposed mechanism underlying Vitamin $\mathrm{D}$ may hold promise in suppressing the cytokine storm and inducing a robust antiviral response in patients with severe COVID-19. The findings of this study urgently require further experimental testing of the suitability of Vitamin $\mathrm{D}$ in combination with IFN- $\alpha$ to combat severe COVID-19 [5].

According to the $\mathrm{WHO}$ website, at the end of November, there are 130 thousand cases. The number of cases is growing every day. The country has had two major waves of morbidity. The first one began on July 1; they began to register cases together with pneumonia, since pneumonia is the main complication of CVI. For July 1, 2020, 18,757 cases were registered. In the city of Nur-Sultan, 15,989 cases have been identified for the entire time. It was detected 11,077 cases in Karaganda region.

\section{Results and Discussion}

The main target in the body for SARS-CoV-2 is the lungs. In Kazakhstan, only 14 cases of children with Kawasaki syndrome have been registered. At the moment, the only case of children with Kawasaki syndrome has been registered in the Karaganda region.

\section{Let's take a clinical case as an example}

A child M. born in 2010 was admitted to the children's hospital. Complaints on admission from the mother's words: Vomiting, loose stools up to 10 times a day, anxiety, rash on the body, hyperemia of the conjunctiva of the eyes, swelling of the eyelids, redness of the palms, pain in the abdomen, weakness, fever up to febrile numbers, and decreased appetite. The next time a skin rash appeared, then conjunctival hyperemia, and then redness of the palms took: Antibacterial therapy, rehydron, smecta, activated carbon, paracetamol, ibufen - no effect.

\section{Allergic history}

Skin rash with this disease for the $1^{\text {st }}$ time.

\section{On objective examination}

$\mathrm{BH} 22 / \mathrm{min}$, heart rate 100/min, $\mathrm{T} 37.5 \mathrm{C}$, blood pressure $90 / 60 \mathrm{~mm} \mathrm{Hg}$, and Art. Blood saturation $96 \%$. The condition is closer to severe due to symptoms of intoxication and dyspeptic syndrome. Consciousness is clear. Pale skin, maculopapular rash on the trunk, limbs. The palms are hyperemic. Hyperemia and edema of the eyes, conjunctiva is markedly hyperemic. Anterior cervical lymph nodes are up to $1 \mathrm{~cm}$ in diameter, in other groups - up to 0.5 $\mathrm{cm}$. They are painless, mobile. Patients breathe freely through the nose. Pharynx - moderate hyperemia of the mucous membranes, the mucous membrane of the lips is hyperemic, dry. There is no shortness of breath. Heart sounds are loud; the rhythm is correct, tachycardia, short systolic murmur at the apex and at the 5 th point, without irradiation. The abdomen is soft on palpation, rumbling along the intestines, painful on palpation, more in the umbilical region. No symptom of peritoneal irritation. Peristalsis is not heard; the anus is closed. The stool is frequent and liquid. Meningeal symptoms are negative.

\section{Laboratory diagnostic tests}

ESR - $10 \mathrm{~mm} / \mathrm{h}$; complete blood count without pathological changes.

\section{Biochemical blood test}

Total protein $57.0 \mathrm{~g} / \mathrm{l} ;$ ALAT - $80.00 \mathrm{IU} / \mathrm{l}$; Vitamin D <10 ng/ml; ACaT - $80.00 \mathrm{IU} / \mathrm{l}$; albumin $33 \mathrm{~g} / \mathrm{l}$, urea $18.7 \mathrm{mmol} / \mathrm{l}$, creatinine $243 \mathrm{mmol} / \mathrm{l}$, glucose $5.1 \mathrm{mmol} / \mathrm{l}$, calcium $2.0 \mathrm{mmol} / \mathrm{l}$, potassium $3.9 \mathrm{mmol} / \mathrm{l}$, sodium $128 \mathrm{mmol} / \mathrm{l}$, bilirubin $5.0 \mathrm{mmol} / \mathrm{l}$, thymol test 3.0, alkaline phosphatase $173 \mathrm{IU} / \mathrm{l}$, amylase $39 \mathrm{U} / \mathrm{l}$, CPK 45, cholesterol $2.17 \mathrm{mmol} / \mathrm{l}$, triglycerides $2.33 \mathrm{mmol} / \mathrm{l}, \mathrm{CRP} 407.9 \mathrm{mg} / \mathrm{l}$, rheumatoid factor +, troponin I $4.9 \mathrm{mg} / \mathrm{ml}$, BNP - natriuretic peptide $<0.05 \mathrm{ng} / \mathrm{ml}$, and ferritin $368.4 \mathrm{ng} / \mathrm{ml}$. Further, an additional study was carried out: Procalcitonin $17.9 \mathrm{ng} / \mathrm{ml}$, interleukin $842.5 \mathrm{pg} / \mathrm{ml}$, and PCR detection of RNA virus COVID-19 coronavirus COVID-19 - negative.

ELISA IgM to SARS-COV-2 coronavirus Result 0.65, ELISA IgG to SARS-COV-2 coronavirus Result 8.7. 
Coagulogram analyzer showed D-dimer $2202.20 \mathrm{ng} / \mathrm{ml}$. Blood gases and electrolytes without pathology. General urine analysis have no pathology.

\section{Instrumental research}

Ultrasound of the hepatobiliopancreatic region, conclusion: Hepatosplenomegaly. Diffuse changes in the parenchyma of the liver and pancreas. ECG conclusion: Sinus tachycardia. Metabolic disorders in the myocardium. Incomplete right bundle branch block.

X-ray survey of the chest organs (1 projection): X-ray pathology in the lungs was not revealed. Plain X-ray of the abdominal organs conclusion: No pathology was revealed.

\section{Cardiac echo}

Bicuspid aortic valve, partially undivided commissure between the right and left coronary cusps, mild aortic regurgitation, dilation of the ascending aorta. Diffuse enlargement of the lumen of the right coronary artery typical for Kawasaki disease, mild hydropericardium. Hypokinesia of the basal lower segment of the left ventricular myocardium; in the study of regional deformity, contractility disorders were not confirmed.

\section{Cardiologist's conclusion}

Multisystem inflammatory syndrome (Kawasaki-like syndrome) associated with COVID-19.

As part of this syndrome, acute renal injury can be occurred. Conclusion by a nephrologist was the following: An increase in urea and creatinine are noted the next day after admission to the outpatient clinic. Feature - preserved diuresis. At the moment, in urine tests - no features. BBA - increased transaminases, hyponatremia, normal potassium, creatinine $243 \mu \mathrm{mol} / \mathrm{L}$, and urea $18.7 \mathrm{mmol} / \mathrm{L}$. Ultrasound of the kidneys - the size is increased. Glomerular filtration rate (GFR) according to the Schwartz formula $24.7 \mathrm{ml} / \mathrm{min}$. Diagnosis: Acute renal injury (prerenal), non-oliguric form. GFR $24.7 \mathrm{ml} / \mathrm{min}$ - as part of Multisystem Inflammatory Syndrome.

\section{Treatment was performed}

Prescribed medications: Antibiotics,

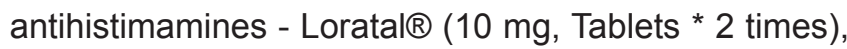
Paracetamol (200 mg, Tablets) Rehydron (18.9 g, 4 r/d. 1 d.) Cef III2 r/d 2 days.

\section{Prescribed OARIT medications}

IV kiovig 2 g/kg - 80 g in 24 h 08.19-20.08.2020. IV methylprednisolone $750 \mathrm{mg}+0.9 \% \mathrm{NaCl}$ solution $200 \mathrm{ml}$ from day 3, followed by oral administration of metiprednisolone at a dose of $1 \mathrm{mg} / \mathrm{kg}$ (according to prednisolone) IV cep32g * 2 times a day, by mouth: Acetylsalicylic acid $500 \mathrm{mg}$ * 3 times 2 days after admission, s/c heparin 200 units/kg per day in 4 injections 2 days after admission, 300 units/kg per day in 4 injections from the $3^{\text {rd }}$ day after admission; IV kvamatel $20 \mathrm{mg}$ once a day.

\section{Conclusion}

The results of fundamental research allow us to assert that Vitamin $D$ is fundamentally necessary for maintaining the normal physiological functioning of the immune system: Activating antibacterial and antiviral defenses, reducing excessive inflammation, etc. Clinical studies and meta-analyzes have shown that reduced levels of $25(\mathrm{OH}) \mathrm{E}$ in the blood contribute to impaired immunity and stimulate excessive inflammation, which adversely affects the health of children: The risk of developing bronchial asthma, obstructive bronchitis, and allergic rhinitis increases.

With COVID-19 in children, complications are given, cytokine and bradykinin storms, when the immune system overreacts to the introduction of the virus. Everything is very individual and depends on immunity. The susceptibility of the organism, the source of infection, transmission factors, and the amount of the virus play a role in the development of multisystem inflammatory syndrome. This is all individual, it is difficult to predict. "Young children" are more seriously ill - decompensation of the body against the background of a viral infection.

For further treatment, he is transferred to the SECMR in Nur-Sultan for biological therapy due to the persistence of inflammatory activity in the blood and changes in echocardiography. It is good that Kawasaki syndrome is rare in children. The available evidence points to the promise of using drugs and Vitamin D supplements for the treatment and prevention of respiratory tract infections, incl. caused by the respiratory syncytial virus $R S V$ and influenza $A$.

\section{References}

1. Torshin IY, Rudakov KV. Combinatorial analysis of the solvability properties of the problems of recognition and completeness of algorithmic models. Part 1: Factorization approach. Pattern Recogn Image Anal. 2017;27(1):16-28. https://doi.org/10.1134/ 
s1054661817010151

2. Torshin IY, Rudakov KV. On metric spaces arising during formalization of problems of recognition and classification. Part 2: Density properties. Pattern Recogn Image Analy. 2016;26(3):483-96. https://doi.org/10.1134/ s1054661816030202

3. Gromova OA, Torshin IY. Vitamin D is a Paradigm Shift. Moscow: GEOTAR-Medial; 2017.

4. Maltsev SV, Mansurova GS. Vitamin D metabolism and ways of implementing its main functions. PM; 2014.

5. Institute of Medicine, Food and Nutrition Board. Dietary Reference Intakes for Calcium and Vitamin D. Washington, DC: National Academy Press; 2010.

6. Yakub MY, Salam RA, Khan FR, Bhutta ZA. Vitamin D supplementation for preventing infections in children under five years of age. Cochrane Database Syst Rev 2016;11(11):CD008824. https://doi.org/10.1002/14651858. cd008824.pub2

PMid:27826955

7. Martineau AR, Jolliffe DA, Hooper RL, Greenberg L, Aloia JF, Bergman $\mathrm{P}$, et al. Vitamin D supplementation to prevent acute respiratory tract infections: Systematic review and meta-analysis of individual participant data. BMJ. 2017;356:i6583. https://doi. org/10.1136/bmj. 6583

PMid:28202713

8. Cannell JJ, Vieth R, Umhau JC, Holick MF, Grant WB, Madronich S, et al. Epidemic influenza and Vitamin D. Epidemiol Infect. 2006;134:1129-40. https://doi.org/10.1017/ s0950268806007175

PMid: 16959053

9. Jollie DA, Griths CJ, Martineau AR. Vitamin D in the prevention of acute respiratory infection: Systematic review of clinical studies. J Steroid Biochem Mol Biol 2013;136:321-9. PMid:23220552

10. Lazareva NB, Rebrova EV, Panteleeva LR. Vitamin $D$ and acute respiratory infections: Prevention or treatment? Med Advice 2019;6(9):116-24. https://doi. org/10.21518/2079-701x-2019-6-116-124

11. Ahmed F. A network-based analysis reveals the mechanism underlying Vitamin $D$ in suppressing cytokine storm and virus in SARS-CoV-2 infection. Front Immunol. 2020;11:590459. https:// doi.org/10.3389/fimmu.2020.590459

PMid:33362771

12. Martineau AR, Jolliffe DA, Greenberg L, Aloia JF, Bergman $P$, Dubnov-Raz G, et al. Vitamin D supplementation to prevent acute respiratory infections: Individual participant data meta-analysis. Health Technol Assess. 2019;23(2):1-44. PMid:30675873

13. Kalinchenko SY, Pigarova EA, Gusakova DA, Plescheva AV. Vitamin D and urolithiasis. Consilium Med 2012;12:97-102.

14. Pludowski P, Holick MF, Pilz S, Wagner CL, Hollis BW, Grant WB, et al. Vitamin D effects on musculoskeletal health, immunity, autoimmunity, cardiovascular disease, cancer, fertility, pregnancy, dementia and mortality-a review of recent evidence. Autoimmun Rev. 2013;12(10):976-89. https://doi.org/10.1016/j. autrev.2013.02.004

PMid:23542507

15. Mithal A. Treatment of Vitamin D Deficiency. Endocrine Case Management ICE/ENDO. United States: Endocrine Society; 2014. p. 37-9. https://doi.org/10.1210/mtp3.9781936704835. ch8

16. Korucu E, Pur Ozyigit L, Ortakoylu MG, Bahadir A, Akalin ES, Kara $A$, et al. Cathelicidin as a link between sarcoidosis and tuberculosis. Sarcoidosis Vasc Diffuse Lung Dis. 2015;32(3):222-7.

\section{PMid:26422567}

17. Stagi S, Bertini F. Vitamin D levels and effects of Vitamin D replacement in children with periodic fever, aphthous stomatitis, pharyngitis, and cervical adenitis (PFAPA) syndrome. Int J Pediatr Otorhinolaryngol. 2014;78(6):964-8. https://doi. org/10.1016/j.ijporl.2014.03.026

PMid:24746456

18. Amaya-Mejia AS, O'Farrill-Romanillos PM, Galindo-Pacheco LV, Vargas-Ortega G, Mendoza-Zubieta V, DelRivero-HernándezLG, et al. Vitamin $\mathrm{D}$ deficiency in patients with common variable immunodeficiency, with autoimmune diseases and bronchiectasis. Rev Alerg Mex. 2013;60(3):110-6.

PMid:24274606

19. Man L, Zhang Z, Zhang M, Li J, Zheng N, Cao Y, et al. Association between Vitamin $D$ deficiency and insufficiency and the risk of childhood asthma: Evidence from a meta-analysis. Int J Clin Exp Med. 2015;8(4):5699-706. PMid:26131154

20. Song $H$, Yang L, Jia C. Maternal Vitamin D status during pregnancy and risk of childhood asthma: A meta-analysis of prospective studies. Mol Nutr Food Res. 2016;61(5):657. https://doi.org/10.1002/mnfr.201600657

PMid:27981740

21. Aryan Z, Rezaei N, Camargo CA Jr. Vitamin D status, aeroallergen sensitization, and allergic rhinitis: A systematic review and meta-analysis. Int Rev Immunol. 2017;36(1):41-53. https://doi.org/10.1080/08830185.2016.1272600 PMid:28102718

22. Charan J, Goyal JP, Saxena D, Yadav P. Vitamin D for prevention of respiratory tract infections: A systematic review and meta-analysis. J Pharmacol Pharmacother. 2012;3(4):300-3. https://doi.org/10.4103/0976-500x.103685 PMid:23326099

23. Khare D, Godbole NM, Pawar SD. [1, 25[OH]2 D3] preand post-treatment suppresses inflammatory response to influenza A (H1N1) infection in human lung A549 epithelial cells. Eur J Nutr 2013;52(4):1405-15. https://doi.org/10.1007/ s00394-012-0449-7 PMid:23015061

24. Bergman $P$, Lindh $A U$. Vitamin $D$ and respiratory tract infections: A systematic review and meta-analysis of randomized controlled trials. PLoS One. 2013;8(6):e65835. https://doi.org/10.1371/ journal.pone. 0065835

PMid:23840373

25. Jat KR. Vitamin $D$ deficiency and lower respiratory tract infections in children: A systematic review and meta-analysis of observational studies. Trop Doct. 2017;47(1):77-84. https://doi. org/10.1177/0049475516644141

PMid:27178217

26. Williams CJ. On the use and administration of cod-liver oil in pulmonary consumption. London J Med. 1849;1:1-18.

27. Hönigsmann $H$. History of phototherapy in dermatology Photochem Photobiol Sci. 2013;12(1):16-21. https://doi. org/10.1039/c2pp25120e

28. Ho-Pham LT, Nguyen ND, Nguyen TT, Nguyen DH, Bui PK, Nguyen VN, et al. Association between Vitamin D insufficiency and tuberculosis in a Vietnamese population. BMC Infect Dis. 2010;10:306. https://doi.org/10.1186/1471-2334-10-306 PMid:20973965

29. Arnedo-Pena A, Juan-Cerdán JV, Romeu-García MA, GarcíaFerrer D, Holguín-Gómez R, Iborra-Millet J, et al. Vitamin D status and incidence of tuberculosis infection conversion in contacts of pulmonary tuberculosis patients: A prospective cohort study. Epidemiol Infect. 2015;143(8):1731-41. https://doi. org/10.1017/s0950268814002386 
PMid:25274036

30. Gao WW, Wang $Y$, Zhang XR, Yin CY, Hu CM, Tian M, et al Levels of 1,25(OH)2D3 for patients with pulmonary tuberculosis and correlations of $1,25(\mathrm{OH}) 2 \mathrm{D} 3$ with the clinical features of TB. J Thorac Dis. 2014;6(6):760-4.

PMid:24977000

31. Greenstein RJ, Su L, Shahidi A, Brown WD, Clifford A, Brown ST. Unanticipated Mycobacterium tuberculosis complex culture inhibition by immune modulators, immune suppressants, a growth enhancer, and Vitamins A and D: Clinical implications. Int J Infect Dis. 2014;26:37-43. https://doi.org/10.1016/j.jij.2014.01.026 PMid:24998461

32. Mehta S, Mugusi FM, Bosch RJ, Aboud S, Urassa W, Villamor E, etal. Vitamin D status and TB treatment outcomes in adult patients in Tanzania: A cohort study. BMJ Open. 2013;3(11):e003703. https://doi.org/10.1136/bmjopen-2013-003703

PMid:24247327

33. Ginde AA, Mansbach JM, Camargo CA. Association between serum 25-hydroxy Vitamin $\mathrm{D}$ level and upper respiratory tract infection in the third national health and nutrition examination survey. Arch Intern Med. 2009;169(4):384-90. https://doi. org/10.1001/archinternmed.2008.560
PMid:19237723

34. Sabetta JR, DePetrillo P, Cipriani RJ, Smardin J, Burns LA Landry ML. Serum 25-hydroxyvitamin $d$ and the incidence of acute viral respiratory tract infections in healthy adults. PLoS One. 2010;5(6):e11088. https://doi.org/10.1371/journal. pone.0011088

PMid:20559424

35. Quraishi SA, Bittner EA, Christopher KB, Camargo CA Jr Vitamin D status and community-acquired pneumonia: Results from the third National Health and Nutrition examination survey. PLoS One. 2013;8(11):e81120. https://doi.org/10.1371/journal. pone.0081120

36. Tran B, Armstrong BK, Ebeling PR, English DR, Kimlin MG, van der Pols JC, et al. Effect of Vitamin D supplementation on antibiotic use: A randomized controlled trial. Am J Clin Nutr. 2014;99(1):156-61. https://doi.org/10.3945/ajcn.113.063271 PMid:24260547

37. Griffin AT, Arnold FW. Review of metabolic, immunologic, and virologic consequences of suboptimal Vitamin D levels in HIV infection. AIDS Patient Care STDS. 2012;26(9):516-25. https:// doi.org/10.1089/apc.2012.0145

PMid:22861070 